\title{
The Landscape and Recent Developments of Civic and Citizenship Education Across the Latin American Region
}

\author{
Andrés Sandoval-Hernández and Daniel Miranda ${ }^{1}$
}

\begin{abstract}
This chapter was invited to provide a description of the landscape of the international dimension of IEA's International Civic and Citizenship Education Study (ICCS) within the Latin American region. These authors possess extensive experience in analyzing and publishing from these datasets. The chapter begins by describing their professional, academic, and personal involvement with IEA's civic education studies. This is followed by an analytical review of peerreviewed articles, books, as well as research projects that included ICCS data as part of their empirical evidence. It also describes the people, institutions, and research teams that have been involved in these projects. The result of this review is divided into two sections: a characterization of the topics that have proven relevant for the region, and mapping of the specific overlaps between these topics and the contents of the ICCS datasets. Finally, there are specific suggestions that could contribute to raising the profile of ICCS as a key resource for the discourse on civic education in Latin America.
\end{abstract}

\section{Introduction}

Twenty years ago, there was relatively modest interest among Latin American educational researchers in the topic of civic education viewed internationally or regionally. In the International Association for the Evaluation of Educational Achievement (IEA) Civic Education Study (CIVED), testing in 1999 and 2000, only Chile and Colombia participated (Torney-Purta et al. 2001; Amadeo et al. 2002). Ten years later, in the first cycle of the IEA's International Civic and Citizenship Education Study (ICCS) (Schulz et al. 2009) there was additional participation with a total of six countries (Mexico, Guatemala, Colombia, Chile, Dominican Republic, and Paraguay). As important, there was a module of questions specific to the region and a report was published of these regional results (Schulz et al. 2011). In ICCS 2016 four of these countries participated again (Mexico, Colombia, Chile, and the Dominican Republic) and Peru joined for the first time (Schulz et al. 2018). The participation of these countries in the IEA studies has meant that, instead of isolated countries providing snapshots of this region, over the past two decades a landscape of countries where civic opportunities and civic education vary greatly can be examined in a comparative fashion.

This growing interest in civic and citizenship education in the region has been coupled with the emergence of a network of researchers across Latin American countries. Currently, this network involves more than 15 institutions and about 30 individuals in the region but also extends to other institutions outside Latin America, such as Harvard University in the United States, the University of Deusto in Spain, and the University of Bath in the United Kingdom where collaborating researchers have been located.

1 This chapter was supported by the National Agency of Research and Development through the grants ANID/ FONDECYT N¹181239, ANID/FONDECYT N¹1190508 and the Center of Social Conflict and Cohesion Studies - COES ANID/FONDAP N¹5130009.

Andrés Sandoval-Hernández, Department of Education, University of Bath, Bath, United Kingdom email: A.Sandoval@bath.ac.uk

Daniel Miranda, Centro de Medición MIDE UC, Escuela de Psicología Pontificia Universidad Católica de Chile, Santiago, Chile

email: damiran1@uc.cl

(C) IEA International Association for the Evaluation of Educational Achievement 2021

B. Malak-Minkiewicz and J. Torney-Purta (eds.), Influences of the IEA Civic

and Citizenship Education Studies, https://doi.org/10.1007/978-3-030-71102-3_22 
The involvement of Andres Sandoval-Hernandez (one of the co-authors of this chapter) with ICCS began in 2010 when he started working at the Research and Analysis Unit of IEA's Data Processing Centre (DPC), in Hamburg, Germany. The activities at this unit consisted of carrying out analysis on IEA datasets across subject areas and offering training focused on secondary analyses of IEA's data. At that time, the data from ICCS 2009 was freshly released and many of the training activities focused on this study. These activities created opportunities for several individuals who are now part of the network of researchers on ICCS across Latin American countries. For example, Ernesto Treviño, Juan Carlos Castillo, Diego Carrasco, Silvia Diazgranados, and Daniel Miranda (the co-author of this chapter), participated in one or more of the workshops organized by IEA and currently participate or have participated in one or more of the multi-year research projects based on analyses of ICCS data.

Other good examples of the impact of IEA activities on the development of research networks and products are the multi-year and multi-institution research projects based on ICCS data that have been funded by national governments (i.e., Chile and Mexico) and by international institutions (i.e., the Inter-American Development Bank). The projects funded by the Chilean National Commission for Science and Technology and the Mexican National Council for Science and Technology, consisted of a series of activities including reciprocal visits among the researchers working at different institutions. These projects culminated in the publication of a book (Sandoval-Hernández et al. 2018) and more than 10 academic chapters and articles focused on civic and citizenship education in Latin America (e.g., Castillo et al. 2014a; GarcíaCabrero et al. 2016; García-Cabrero et al. 2017; Miranda et al. 2015). The project entitled Regional System for the Evaluation and Development of Citizenship Competences (SREDECC) was founded in 2005 with the economic aid of the Inter-American Development Bank. The SREDECC was operationally supported by the Regional Center for the Promotion of Books in Latin America and the Caribbean (CERLALC). One of the main outcomes of this project was the development of a Latin American module of questions for ICCS 2009 and the publication of nine reports associated with its results (several in Spanish): a report summarizing citizenship curricula in the region, a regional report about civic knowledge of the students in the region, six national reports (Chile, Colombia, Guatemala, Mexico, Paraguay, and the Dominican Republic) and a regional report in Spanish about successful practices in citizenship education (Reimers and Villegas-Reimers 2011).

It can be said that some of the main achievements of ICCS in Latin America have been the development of technical expertise for the evaluation of civic and citizenship education, impact on the policy and practice of the countries that have participated in the IEA studies, and the establishment of a community of researchers (many at universities) who are interested in the development of in-depth studies based on secondary analyses of ICCS data. In this chapter, we focus on the academic products of this community of researchers, a characterization of the topics that have particular relevance for the region and a mapping of the specific overlaps between these topics and the contents of the ICCS datasets. In the remainder of this chapter, we outline a landscape of the research outputs of ICCS in Latin America, as well as some specific suggestions to raise the profile of ICCS as a key resource for enhancing future discussions on civic education in the region.

\section{A Landscape of Research Outputs Based on the ICCS in Latin America}

The next section describes a set of scholarly products that have investigated issues relevant to the region using ICCS data. We identified a total of more than 30 books, book chapters, and peer-reviewed papers since 2004. Before 2013, four publications were produced: one book, one book chapter, and two articles in peer-reviewed journals. From this period, it is important to highlight the book analyzing CIVED data by Torney-Purta et al. which was published by the Organization of American States (OAS) in English (2004b) and Spanish (2004a) through its Unit 
for Social Development and Education and also the paper by Reimers (2007). These publications are valuable not only for their results relatively early in this 12-year period, but also because they constituted a reference point for setting the research agenda for scholars. For example, Reimers highlighted the limited impact that the IEA CIVED was having on teaching practice and school culture (Reimers 2007). Torney-Purta et al. (2004b) highlighted the potential of examining civic knowledge on a detailed item by item basis. This was possible because one test was administered to all CIVED respondents, and matrix sampling of items was instituted only in ICCS 2009. Young people's responses to CIVED items and scales measuring attitudes, values, and willingness to participate in the political and civic process also received major attention in the OAS report.

Since 2014 the numbers of publications have increased. Two books, six book chapters (see Table 1), and 18 papers (see Table 2) have been produced during this second period.

Table 1: Books and book chapters

\begin{tabular}{|c|c|c|c|c|}
\hline Author & Year & Title and publisher & Language & Type \\
\hline $\begin{array}{l}\text { Torney-Purta, J., Amadeo, } \\
\text { J.-A., \& Pilotti, F. }\end{array}$ & 2004 & $\begin{array}{l}\text { Strengthening democracy in the Americas } \\
\text { through civic education: An empirical analysis } \\
\text { highlighting the views of students and teachers. } \\
\text { Washington, DC: Organization of American } \\
\text { States. }\end{array}$ & English/Spanish & Book \\
\hline Cox, C., \& Castillo, J. C. & 2015 & $\begin{array}{l}\text { Aprendizaje de la ciudadanía: Contextos, } \\
\text { experiencias y resultados [Citizenship learning: } \\
\text { Contexts, experiences and results]. Santiago, } \\
\text { Chile: Ediciones UC. }\end{array}$ & Spanish & Book \\
\hline $\begin{array}{l}\text { Miranda, D., Castillo, J. C., \& } \\
\text { Sandoval-Hernandez, A. }\end{array}$ & 2015 & $\begin{array}{l}\text { Desigualdad y conocimiento cívico: Chile en } \\
\text { comparación internacional [Inequality and civic } \\
\text { knowledge: Chile in international comparison]. } \\
\text { In C. Cox, \& J.C. Castillo (Eds.), Aprendizaje } \\
\text { de la Ciudadanía. Contextos, Experiencias } \\
\text { y Resultados [Citizenship learning contexts, } \\
\text { experiences and results]. Santiago, Chile: } \\
\text { Ediciones UC. }\end{array}$ & Spanish & Book chapter \\
\hline $\begin{array}{l}\text { García-Cabrero, B., } \\
\text { Sandoval-Hernández, A., } \\
\text { Treviño, E., Diazgranados- } \\
\text { Ferrans, S., \& Martínez, G. }\end{array}$ & 2017 & $\begin{array}{l}\text { Civics and citizenship: Theoretical models and } \\
\text { experiences in Latin America. Amsterdam, the } \\
\text { Netherlands: Sense Publishers. }\end{array}$ & English & Book \\
\hline $\begin{array}{l}\text { Treviño, E., Béjares C., } \\
\text { Villalobos C., \& Naranjo E. }\end{array}$ & 2017 & $\begin{array}{l}\text { Building citizenship in the schools of Chile, } \\
\text { Colombia and Mexico. In B., García-Cabrero, } \\
\text { A. Sandoval-Hernández, E. Treviño-Villareal, } \\
\text { S.D. Ferráns, M.G.P. Martínez (Eds.), Civics and } \\
\text { citizenship. Rotterdam, the Netherlands: Sense } \\
\text { Publishers. }\end{array}$ & English & Book chapter \\
\hline $\begin{array}{l}\text { García-Cabrero, B., } \\
\text { Sandoval-Hernández, A., \& } \\
\text { Martínez, M. G. P. }\end{array}$ & 2017 & $\begin{array}{l}\text { Affective and cognitive processes as } \\
\text { determinants of civic participation in Latin } \\
\text { American countries. In B., García-Cabrero, } \\
\text { A. Sandoval-Hernández, E. Treviño-Villareal, } \\
\text { S.D. Ferráns, M.G.P. Martínez (Eds.), Civics and } \\
\text { citizenship (pp. 127-153). Rotterdam: Sense. }\end{array}$ & English & Book chapter \\
\hline $\begin{array}{l}\text { Diazgranados-Ferráns, S. D., } \\
\text { \& Sandoval-Hernández, A. }\end{array}$ & 2017 & $\begin{array}{l}\text { The civic competence gaps in Chile, Colombia } \\
\text { and Mexico and the factors that account } \\
\text { for the civic knowledge gap: Evidence from } \\
\text { the } 2009 \text { International Civic and Citizenship } \\
\text { Education Study (ICCS). In B., García-Cabrero, } \\
\text { A. Sandoval-Hernández, E. Treviño-Villareal, } \\
\text { S.D. Ferráns, M.G.P. Martínez (Eds.), Civics and } \\
\text { citizenship (pp. 155-192). Rotterdam: Sense. }\end{array}$ & English & Book chapter \\
\hline
\end{tabular}


Table 1: Books and book chapters (contd.)

\begin{tabular}{|c|c|c|c|c|}
\hline Author & Year & Title and publisher & Language & Type \\
\hline $\begin{array}{l}\text { Treviño, E., Sandoval- } \\
\text { Hernández. A., Miranda, D., } \\
\text { Rutkowski, D., \& Matta, T. }\end{array}$ & 2019 & $\begin{array}{l}\text { Invarianza de las escalas de nivel } \\
\text { socioeconómico en estudios internacionales. } \\
\text { In J. Manzi, M. R. García, \& S. Taut (Eds.), } \\
\text { Validez de evaluaciones educacionales en Chile y } \\
\text { Latinoamérica (pp. 301-328). Santiago, Chile: } \\
\text { Ediciones Universidad Católica de Chile. }\end{array}$ & Spanish & Book chapter \\
\hline $\begin{array}{l}\text { Castillo, J. C., Miranda, D., \& } \\
\text { Bonilla, A. }\end{array}$ & 2019 & $\begin{array}{l}\text { Medición de actitudes hacia la igualdad } \\
\text { de derechos entre géneros en pruebas } \\
\text { internacionales: Implicacias respecto a su } \\
\text { validez. In J. Manzi, M. R. García, \& S. Taut } \\
\text { (Eds.), Validez de evaluaciones educacionales en } \\
\text { Chile y Latinoamérica (pp. 329-356). Santiago, } \\
\text { Chile: Ediciones Universidad Católica de Chile. }\end{array}$ & Spanish & Book chapter \\
\hline
\end{tabular}

Table 2: Peer-reviewed articles

\begin{tabular}{|c|c|c|c|c|}
\hline Author & Year & Title and publisher & Language & Type \\
\hline Reimers, F. & 2007 & $\begin{array}{l}\text { Civic education when democracy is in flux: } \\
\text { The impact of empirical research on policy } \\
\text { and practice in Latin America. Citizenship and } \\
\text { Teacher Education, 3(2), 5-21. }\end{array}$ & English & paper \\
\hline Caro, D. H., \& Schulz, W. & 2012 & $\begin{array}{l}\text { Ten hypotheses about tolerance toward } \\
\text { minorities among Latin American adolescents. } \\
\text { Citizenship, Social and Economic Education, } \\
\text { 11(3), 213-234. }\end{array}$ & English & paper \\
\hline $\begin{array}{l}\text { Castillo, J.C, Miranda, D., } \\
\text { Bonhomme, M., Cox, C., \& } \\
\text { Bascopé, M.. }\end{array}$ & $2014 a$ & $\begin{array}{l}\text { Social inequality and changes in students' } \\
\text { expected political participation in Chile. } \\
\text { Education, Citizenship and Social Justice, 9(2), } \\
\text { 140-156. }\end{array}$ & English & paper \\
\hline $\begin{array}{l}\text { Valencia Serna, A., \& Vivas } \\
\text { Pacheco, H. }\end{array}$ & 2014 & $\begin{array}{l}\text { La apertura a la discusión en la sala de } \\
\text { clases y su relación con la educación para } \\
\text { la ciudadanía [The open classroom for } \\
\text { discussion and its relation with citizenship } \\
\text { education]. Revista Colombiana de Educación, } \\
66,223-242 \text {. }\end{array}$ & Spanish & paper \\
\hline $\begin{array}{l}\text { Collado, D., Lomos, C., \& } \\
\text { Nicaise, I. }\end{array}$ & 2015 & $\begin{array}{l}\text { The effects of classroom socio-economic } \\
\text { composition on student's civic knowledge } \\
\text { in Chile. School Effectiveness and School } \\
\text { Improvement, 26(3), 415-440. }\end{array}$ & English & paper \\
\hline $\begin{array}{l}\text { Castillo, J.C, Miranda, D., } \\
\text { Bonhomme, M., Cox, C., \& } \\
\text { Bascopé, M. }\end{array}$ & 2015 & $\begin{array}{l}\text { Mitigating the political participation gap from } \\
\text { the school: the roles of civic knowledge and } \\
\text { classroom climate. Journal of Youth Studies, } \\
\text { 18(1), 16-35. }\end{array}$ & English & paper \\
\hline $\begin{array}{l}\text { Bascopé, M., Bohnomme, } \\
\text { M., Cox, C., Castillo, J.C., \& } \\
\text { Miranda, D. }\end{array}$ & 2015 & $\begin{array}{l}\text { Curricular guidelines and citizenship attitudes } \\
\text { in Latin American students: a comparative } \\
\text { analysis. Revista Latinoamericana de Ciencias } \\
\text { Sociales, Niñez y Juventud, 13(2), 1169-1190. }\end{array}$ & English & paper \\
\hline Ortiz, I & 2016 & $\begin{array}{l}\text { Actitudes de los estudiantes en escuelas } \\
\text { segregadas y en escuelas inclusivas, hacia la } \\
\text { tolerancia social y la convivencia entre pares } \\
\text { [Attitudes of students in segregated schools and } \\
\text { in inclusive schools, towards social tolerance and } \\
\text { peer coexistence]. Calidad en la educación, (44), } \\
68-97 .\end{array}$ & Spanish & paper \\
\hline
\end{tabular}


Table 2: Peer-reviewed articles (contd.)

\begin{tabular}{|c|c|c|c|c|}
\hline Author & Year & Title and publisher & Language & Type \\
\hline $\begin{array}{l}\text { García-Cabrero, B., Pérez- } \\
\text { Martínez, M. G., Sandoval- } \\
\text { Hernández, A., Caso-Niebla, } \\
\text { J., \& Díaz, C. }\end{array}$ & 2016 & $\begin{array}{l}\text { Assessing two theoretical frameworks of } \\
\text { civic engagement. Journal of Social Science } \\
\text { Education, 38-52. }\end{array}$ & English & paper \\
\hline Chaux, E., \& León, M. & 2016 & $\begin{array}{l}\text { Homophobic attitudes and associated factors } \\
\text { among adolescents: A comparison of six Latin } \\
\text { American countries. Journal of homosexuality, } \\
63(9), 1253-1276 .\end{array}$ & English & paper \\
\hline $\begin{array}{l}\text { Treviño, E., Béjares, C., } \\
\text { Villalobos, C., \& Naranjo, E. }\end{array}$ & 2017 & $\begin{array}{l}\text { Influence of teachers and schools on students' } \\
\text { civic outcomes in Latin America. The Journal of } \\
\text { Educational Research, 110(6), 604-618. }\end{array}$ & English & paper \\
\hline $\begin{array}{l}\text { Miranda, D., Castillo, J.C., \& } \\
\text { Sandoval-Hernández, A. }\end{array}$ & 2017 & $\begin{array}{l}\text { Young citizens participation: Empirical testing } \\
\text { of a conceptual model. Youth \& Society, 52(2), } \\
251-271 .\end{array}$ & English & paper \\
\hline $\begin{array}{l}\text { Treviño, E., Béjares, C., } \\
\text { Villalobos, C., \& Naranjo, E. }\end{array}$ & 2018 & $\begin{array}{l}\text { Forms of youth political participation and } \\
\text { educational system: The role of the school } \\
\text { for 8th grade students in Chile. Young, 27(3), } \\
279-303 \text {. }\end{array}$ & English & paper \\
\hline $\begin{array}{l}\text { Webster, N., Sausner, E., } \\
\text { Alobaibi, B., \& Patterson, A. }\end{array}$ & 2018 & $\begin{array}{l}\text { The intersection of civic engagement and } \\
\text { civic attidues among Latino youth through a } \\
\text { factor analysis. Journal of Social Change, 10(1), } \\
\text { 159-168. }\end{array}$ & English & paper \\
\hline $\begin{array}{l}\text { Sandoval-Hernádez, A., } \\
\text { Rutkowski, D., Matta, T., \& } \\
\text { Miranda, D. }\end{array}$ & 2019 & $\begin{array}{l}\text { Pensémoslo de nuevo: ¿podemos comparar } \\
\text { las escalas de antecedentes socioeconómicos? } \\
\text { [Back to the drawing board: Can we compare } \\
\text { socio-economic background scales?]. Revista de } \\
\text { Educacion, (383), 37-61. }\end{array}$ & Spanish/English & paper \\
\hline Snow, K., \& Kennedy, K. & 2019 & $\begin{array}{l}\text { Alienated and disaffected students: } \\
\text { Exploring the civic capacity of } \\
\text { 'Outsiders' in Latin America. Education, } \\
\text { Citizenship and Social Justice. https://doi. } \\
\text { org/10.1177/1746197919886877 }\end{array}$ & Spanish/English & paper \\
\hline $\begin{array}{l}\text { Carrasco, D., Banerjee, R., } \\
\text { Treviño, E., \& Villalobos, C. }\end{array}$ & 2019 & $\begin{array}{l}\text { Civic knowledge and open classroom } \\
\text { discussion: explaining tolerance of corruption } \\
\text { among 8th-grade students in Latin America. } \\
\text { Educational Psychology, 40(2), 186-206. }\end{array}$ & Spanish/English & paper \\
\hline $\begin{array}{l}\text { Martinez, L., Cumsille, P., } \\
\text { Loyola, I., \& Castillo, J.C. }\end{array}$ & 2020 & $\begin{array}{l}\text { Patterns of civic and political commitment } \\
\text { in early adolescence. The Journal of Early } \\
\text { Adolescence, } 40(1), 5-27 \text {. }\end{array}$ & English & paper \\
\hline
\end{tabular}

Furthermore, several masters and doctoral theses were developed between 2013 and 2019. Table 3 lists these documents. Most of the theses came from departments of sociology, psychology, and education, which can be considered a good representation of the several disciplinary perspectives that are covered in ICCS questions. The edited book published in 2017 introduced interpretations using Robert Selman's theory about informed social reflection, which provides a valuable new perspective on civic education generally (not only in Latin America).

Additionally and importantly, since 2007, seven multi-year, externally funded, research projects were carried out. Five of them were funded by the National Commission of Science and Technology of Chile (CONICYT), one by the Inter-American Development Bank (BID), and one by the Mexican National Council for Science and Technology (CONACYT) (see Table 4). All these projects focused on the historical and current context of the civic culture of Latin American countries. They consider aspects such as dictatorships in the region in recent decades, political 
Table 3: Doctoral and masters theses

\begin{tabular}{|c|c|c|c|c|}
\hline Author & Year & Title and publisher & Status & Type \\
\hline Angélica Valencia & 2013 & $\begin{array}{l}\text { La educación para la ciudadanía en } \\
\text { Colombia: un análisis a partir de las pruebas } \\
\text { internacionales sobre educación cívica de } \\
\text { la IEA. School of Sociology, Universidad del } \\
\text { Valle. }\end{array}$ & Finished & Thesis \\
\hline Silvia Diazgranados & 2016 & $\begin{array}{l}\text { The civic knowledge gaps in Chile, Colombia } \\
\text { and Mexico: An application of the Oaxaca- } \\
\text { Blinder decomposition method using data } \\
\text { from the } 2009 \text { International Civic and } \\
\text { Citizenship Education Study (ICCS). Ed.D. in } \\
\text { Human Development and Education, Harvard } \\
\text { University. }\end{array}$ & Finished & Thesis \\
\hline Alex Guerrero & 2016 & $\begin{array}{l}\text { Perfiles de escuela en formación ciudadana. } \\
\text { Master in Sociology, Sociology Institute, } \\
\text { Pontificia Universidad Católica de Chile. }\end{array}$ & Finished & Thesis \\
\hline Amgelica Bonilla & 2016 & $\begin{array}{l}\text { Tolerancia a la diversidad social de los } \\
\text { estudiantes chilenos según determinantes } \\
\text { socioeconómicos y de género: Reevaluando } \\
\text { los efectos de la composición social de las } \\
\text { escuelas. Master in Sociology, Sociology } \\
\text { Institute, Pontificia Universidad Católica de } \\
\text { Chile. }\end{array}$ & Finished & Thesis \\
\hline Francisco Carreño & 2016 & $\begin{array}{l}\text { Predictores de la confianza institucional: el } \\
\text { caso de Chile. Master in Sociology, Sociology } \\
\text { Institute, Pontificia Universidad Católica de } \\
\text { Chile. }\end{array}$ & Finished & Thesis \\
\hline Daniel Miranda & 2018 & $\begin{array}{l}\text { Inequality and citizenship: an intergenerational } \\
\text { approach. Ph.D. Program, Sociology Institute, } \\
\text { Pontificia Universidad Católica de Chile. }\end{array}$ & Finished & Thesis \\
\hline Carolina García & $2018 n$ & $\begin{array}{l}\text { Interpretaciones y paradojas de la educación } \\
\text { ciudadana en Chile: una aproximación } \\
\text { comprensiva desde las significaciones } \\
\text { ciudadanas y pedagógicas de los profesores de } \\
\text { historia. Educational science program, Faculty } \\
\text { of Education, Pontificia Universidad Católica } \\
\text { de Chile. }\end{array}$ & Finished & Thesis \\
\hline Loreto Muñoz & 2019 & $\begin{array}{l}\text { Actitudes hacia la igualdad de género en } \\
\text { adolescentes chilenos: ¿cómo influyen los } \\
\text { padres en sus hijos? Master in Sociology, } \\
\text { Sociology Institute, Pontificia Universidad } \\
\text { Católica de Chile. }\end{array}$ & Finished & Thesis \\
\hline Carolina Miranda & 2019 & $\begin{array}{l}\text { Expected political participation and attitudes } \\
\text { toward equality: the role of gender. Master } \\
\text { in Sociology, Sociology Institute, Pontificia } \\
\text { Universidad Católica de Chile. }\end{array}$ & Finished & Thesis \\
\hline
\end{tabular}

disaffection of citizens observed in decreasing levels of institutional trust and/or voter turnout, and, finally, academic and public policy concerns about poor results in international evaluations of citizenship education. These projects have been oriented to understand civic education and potential outcomes in Latin American countries using CIVED and ICCS data. Some researchers have collected further qualitative and quantitative data (cross-sectional and longitudinal), which is a potential source for new analysis and publications by scholars. These are among the best examples of the future use of findings from the ICCS studies and how they impact the improvement of civic education. 
Table 4: Externally funded research projects using civic and citizenship education data

\begin{tabular}{|c|c|c|}
\hline Author & Period & Project title \\
\hline - Banco Interamericano de Desarrollo & 2007 to 2011 & $\begin{array}{l}\text { Sistema Regional de Desarrollo } \\
\text { y Evaluación de Competencias } \\
\text { Ciudadanas (SREDECC). Funded by } \\
\text { BID }\end{array}$ \\
\hline $\begin{array}{l}\text { - Cristian Cox, Faculty of Education, Pontificia } \\
\text { Universidad Católica de Chile } \\
\text { - Juan Carlos Castillo, Measurement Center } \\
\text { MIDE UC, Pontificia Universidad Católica de } \\
\text { Chile } \\
\text { - Daniel Miranda, Pontificia Universidad } \\
\text { Católica de Chile } \\
\text { - Martín Bascopé, Faculty of Education, } \\
\text { Pontificia Universidad Católica de Chile }\end{array}$ & 2012 to 2014 & $\begin{array}{l}\text { Socialización política y experiencia } \\
\text { escolar: Chile en contexto } \\
\text { internacional. Funded by CONICYT }\end{array}$ \\
\hline $\begin{array}{l}\text { - Benilde García-Cabrero, National Autonomous } \\
\text { - Aniversity of Mexico, Mexico } \\
\text { - Andrés Sandoval-Hernández, United Kingdom } \\
\text { - Ernesto Treviño-Villareal, Pontifical Catholic } \\
\text { University of Chile, Chile } \\
\text { - Silvia Diazgranados Ferráns, Harvard } \\
\text { Graduate School of Education, USA } \\
\text { - María Guadalupe Pérez Martínez, CONACYT } \\
\text { - Autonomous University of Aguascalientes, } \\
\text { Mexico }\end{array}$ & 2014 to 2016 & $\begin{array}{l}\text { The Civic Participation of High } \\
\text { School Students in Mexico, Chile } \\
\text { and Colombia: A Comparative } \\
\text { Analysis. Funded by CONACYT }\end{array}$ \\
\hline $\begin{array}{l}\text { - Rodrigo Mardones, School of Political Science, } \\
\text { Pontificia Universidad Católica de Chile } \\
\text { - Alejandra Marinovic, Universidad Adolfo } \\
\text { Ibañez }\end{array}$ & 2017 to 2019 & $\begin{array}{l}\text { Citizenship education as a Public } \\
\text { Policy. Funded by CONICYT }\end{array}$ \\
\hline $\begin{array}{l}\text { - Ernesto Treviño, Faculty of Education, } \\
\text { Pontificia Universidad Católica de Chile } \\
\text { - Diego Carrasco, Measurement Center MIDE } \\
\text { UC, Pontificia Universidad Católica de Chile } \\
\text { - Cristobal Villalobos, Faculty of Education, } \\
\text { Pontificia Universidad Católica de Chile }\end{array}$ & 2018 to 2020 & $\begin{array}{l}\text { Sistema escolar chileno y el } \\
\text { desarrollo de resultados cívicos. } \\
\text { Formas de implementación, } \\
\text { mecanismos de recontextualización } \\
\text { de la política educativa e influencia } \\
\text { de la escuela en el conocimiento, } \\
\text { actitudes y participación cívica de los } \\
\text { jóvenes. Funded by CONICYT }\end{array}$ \\
\hline $\begin{array}{l}\text { - Cristian Cox, Faculty of Education, Pontificia } \\
\text { - Universidad Católica de Chile } \\
\text { - Uuan Carlos Castillo, School of Sociology, } \\
\text { Universidad de Chile } \\
\text { - Daniel Miranda, Measurement Center MIDE } \\
\text { UC, Pontificia Universidad Católica de Chile } \\
\text { - Camila Jara, Faculty of Education, Universidad } \\
\text { Diego Portales }\end{array}$ & 2018 to 2021 & $\begin{array}{l}\text { Socialización política y educación } \\
\text { para la ciudadanía: el rol de la familia } \\
\text { y de la escuela. Funded by CONICYT }\end{array}$ \\
\hline $\begin{array}{l}\text { - Daniel Miranda, Measurement Center MIDE } \\
\text { UC, Pontificia Universidad Católica de Chile }\end{array}$ & 2019 to 2022 & $\begin{array}{l}\text { Participación Ciudadana Juvenil: } \\
\text { entre la reproducción social y la } \\
\text { socialización política. }\end{array}$ \\
\hline
\end{tabular}


These projects have consisted of in-depth investigations concerned with different levels or aspects of education and different agents involved in the process of citizenship education. At the individual level, the research teams have examined the role of family characteristics (such as socioeconomic background, socialization practices, and attitudinal patterns) and its association with civic outcomes, particularly civic knowledge and citizenship participation. At the school level, these projects have examined the influence of school characteristics and processes on civic outcomes. For example, they investigate teaching practices and approaches designed to produce a more in-depth understanding of this dimension of the school experience than in previous projects and publications. Finally, at the public policy level, they are producing information about changes and stabilities of policies and what this means for the future.

\section{Topics Addressed in the Latin American Publications}

A review of these scholarly products allows us to map the ICCS analyses and results onto the topics that are considered especially relevant for the region. Examining the dependent variables found in the publications and projects described above, we conclude that scholars of the region, besides civic knowledge, have been mainly interested in two topics: citizenship participation and students' attitudes toward equality and tolerance.

Even though civic knowledge is one of the main aspects of all IEA studies including ICCS, not many publications using Latin American data have focused on it, only three articles and two book chapters (in addition to the IEA national and international reports). As in other international largescale assessments (ILSA), the countries of the region obtain low achievement scores compared to the international averages. For those countries that have participated in ICCS 2009 and 2016 , an increase in the average levels of civic knowledge was observed with the exception of Chile, where results showed no significant change between the two time points. In the same vein, as in other regions of the world, the individual factors that have a consistent association with civic knowledge are students' home literacy resources, gender (with females obtaining higher scores in almost all countries), expected years of education and perception of openness for discussion in classroom (Castillo et al. 2015; Collado et al. 2015; Torney-Purta et al. 2004; Treviño et al. 2017; Valencia Serna and Vivas Pacheco 2014). Regarding the contextual school-level factors, the socioeconomic composition of the school and open classroom for discussion are both strongly and consistently associated with students' levels of civic knowledge (Castillo et al. 2015; Collado et al. 2015; Miranda et al. 2015).

As mentioned before, citizens' participation has also been a topic studied by Latin American scholars. On the one hand, there are some efforts oriented to its conceptualization (Miranda 2018; Miranda et al. 2017). On the other hand, efforts have also been oriented to explaining different types of participation. For instance, authors have shown that family socioeconomic measures are closely related to differences in expected formal participation among students (Castillo et al. 2014b; Castillo et al. 2015). Additionally, the same authors have found that some school practices, such as the openness of classrooms for discussion, could help to ameliorate intergenerational inequalities related to low civic and political participation. In the case of participation in protests or demonstrations, some authors have shown that the discussion of political and social issues with family and peers is one of the main factors associated with this type of participation (Treviño et al. 2017; Treviño et al. 2018). And in the case of community or social participation, several analyses have pointed out that political discussion and the perception of the openness of classrooms for discussion have a positive association with this type of participation, while civic knowledge has a negative one (Martínez et al. 2019; Valencia Serna and Vivas Pacheco 2014). Although several authors in the region have addressed the topic of participation, further analyses are needed in order to understand some unexpected results (e.g., the negative association between community participation and civic knowledge) and changes across time, just to mention two issues (Miranda 2018). 
Tolerance and attitudes toward equal rights for immigrants or ethnic minorities is another topic that has received considerable attention in the region. A number of peer-reviewed papers (Caro and Schulz 2012; Sandoval-Hernández et al. 2018), as well as several master's theses (see Table 3) have addressed this topic. This increasing interest is consistent with the changing societal patterns of migration and demands for equality from socially disadvantaged groups. For this reason, research on this topic has considerable potential to produce relevant information to inform policy development in the future Latin American context. Some of the results of the papers that investigate this topic indicate that socio-economic position and gender play relevant roles in explaining different levels of support for equal rights for minority groups.

Another interesting pattern is that a large proportion of the research publications with ICCS data have been focused on three Latin American countries: Mexico, Chile, and Colombia. The other Latin American countries that have participated in ICCS, such as Guatemala, Dominican Republic, and Paraguay in 2009, and Guatemala and Peru in 2016, have received less attention. This could be, at least in part, due to the availability of research grants in Mexico, Colombia, and Chile, and the availability of skilled personnel in well-developed evaluation centers. Although the BID launched a first Regional System for the Evaluation and Development of Citizenship Competences (SREDECC) that originally included Chile, Colombia, México, Guatemala, Paraguay, and the Dominican Republic, it appears that only the first three countries implemented a sustainable strategy to follow-up on the actions initiated by SREDECC (Reimers and Villegas-Reimers 2011).

An analysis of the set of scholarly publications covered here suggests that the Latin American Module of ICCS (Schulz et al. 2011) has received relatively little attention. Many of the politically sensitive scales included in the Latin American Module remain practically unexplored (e.g., tolerance to corruption, authoritarian attitudes, disobedience to law, and peaceful co-existence). Of even more interest, in the ICCS 2009, a set of sixteen items measuring civic knowledge with a focus on Latin American issues was administered. Regardless of the analytical possibilities of this scale, it has not received attention from scholars.

We know that at least one of the current research projects mentioned above is oriented to deepen understanding of topics such as tolerance for corruption or authoritarian attitudes (see Socialización política y educación para la ciudadanía in Table 4). The results of such analyses are anticipated with interest by practitioners and policymakers, as was made clear by Carlos Montes, President of the Chilean Senate during the Seminar Youth and Learning of Democratic Citizenship organized by the Center for the Study of Conflict and Social Cohesion (COES) ${ }^{2}$ in Santiago, Chile in August 2018.

\section{Additional Important Topics for the Latin American Research Agenda}

As described above, the research carried out with ICCS data can be characterized as coming from several disciplines. Building on these diverse perspectives, this section proposes three research topics whose investigation could either fill gaps found during our mapping exercise, or represent topics with untapped potential to address relevant issues in the current context of Latin America.

\section{Promote the use of information available in ICCS that has been minimally used in the past but is especially relevant for the region.}

Some examples would be secondary analysis covering topics such as authoritarianism, corruption in government, and attitudes toward equality of rights for disadvantaged groups (e.g., indigenous people, immigrants, as well as geographical inequalities). A review written in English of secondary analyses that had been published in Spanish would be valuable (e.g., those in the tables). That could parallel the recent review of such articles in English (Knowles et al. 2018). Another example is further investigation of the role of schools in the development of civic knowledge and in

2 More information about this multidisciplinary research center can be found in https://coes.cl/ 
particular the participatory opportunities that they provide. Even though there are some papers on these topics (see Table 2), it is clear that more research, from different disciplines, theoretical perspectives and analytical approaches is needed to more fully understand the role of schools along with their actors and processes in ensuring that young people are prepared to undertake their roles as citizens. This is generally important internationally, but especially in Latin America where there is often little space in the curriculum, and or where the democracy is at a crossroad in several countries of the regions questioned mainly by younger generations.

\section{Continue deepening our understanding of the role played by gender in relation to different civic outcomes.}

Results of research carried out in the region and elsewhere, indicate that the gender of the students plays a relevant role in relation to several civic outcomes. For example, in every country and in every cycle of ICCS, females tend to be more tolerant, empathic, and to participate more than males (Sandoval-Hernández et al. 2018). This is probably one of the best-established patterns in the body of research using ICCS data, however, we still need to understand the social/pedagogical mechanisms that explain how and why this is the case. Research on these topics could produce valuable evidence to inform the design of policies and interventions aimed at constructing a more egalitarian society when these young people become adults. On the one hand, understanding how attitudes toward equality are developed in boys and girls; while on the other, evaluating the different ways in which genders participate in the demand for equal rights through conventional activities or using alternative channels.

\section{Continue deepening the understanding of how education systems continue to reproduce political inequalities.}

Similar to gender, students' socioeconomic status is known to be one of the factors consistently associated with several civic outcomes. For example, it is a well-established pattern that students from more affluent or educated families tend to report higher levels of interest in conventional and social movement participation. Despite the fact that there are several studies focusing on or including this topic, we still need to understand this association, and more importantly, if and how we can contribute to changing the role of education from reproducing to compensating for political and civic inequalities. In this regard, some promising approaches are those that take advantage of the possibility of monitoring trends with ICCS data to focus on the intergenerational transmission of these types of inequalities.

\section{Conclusion and Discussion}

The main objective of this chapter is to describe and explore the landscape of the research results from using ICCS data within the Latin American region. We did so based on our personal and professional involvement in the field. Andres Sandoval-Hernandez had experience working at the research unit of IEA, moving to the University of Bath, where he has kept civic and citizenship education and particularly ICCS at the heart of his research interests. Daniel Miranda has a trajectory that started with his participation in grants about the topic and his PhD studies in Sociology at the Pontificia Universidad Católica of Chile, and continued with his professional involvement in two research institutes within that university: Center of Measurement MIDE UC and the Center for the Study of Conflict and Social Cohesion. He has been co- and principalinvestigator in a number of multi-year research projects that make extensive use of ICCS data.

Our experience working with IEA data and the mapping exercise included in this chapter allowed us to identify what we believe are the most important successes and also the barriers to increasing the impact of ICCS in the policy and practice discussions of the region; as well as providing some recommendations that could help to address them. The barriers include the following:

A limited number of researchers who possess the expertise to analyze and interpret data from large-scale assessment data. 
As was said before, one of the positive outcomes of the participation of Latin American countries in ICCS was the emergence of a network of researchers in the region. Nevertheless, there is still much to be done. We identified only 36 peer-reviewed scholarly articles, chapters, and books for inclusion in our landscape, and those works were co-authored by about 30 individuals. This is a thriving community of researchers committed to the improvement of civic and citizenship education in Latin America, but much more could be done in terms of building capacity that extends across the region. As Torney-Purta et al. (2010) recognize, the interdisciplinary nature of civic and citizenship education tends to create a fragmentary picture of the field. As mentioned before, researchers using ICCS data work in diverse fields including political science, educational psychology, sociology, and social studies education. This interdisciplinarity represents a strength, but it also means that many of the people interested in the topic lack the technical training that would allow them to analyze and interpret the results of large-scale assessments like ICCS.

\section{Lack of technical documentation and a limited number of training events available in Spanish}

The communications team at IEA does a great job at disseminating their studies and results, and the Research and Analysis Unit does an excellent job at offering options to build capacity in secondary analysis techniques of their datasets. Good examples of this are the offering of a very comprehensive Training Portfolio, the video tutorials available on the web, and the IERI Academies in collaboration with the Educational Testing Service (ETS). ${ }^{3}$ All these efforts, however, use English as the main language of instruction. This is a major barrier for many researchers in Latin America since English is not widely spoken in the region. According to the English Proficiency Index (Education First 2018), Latin America is the weakest of all regions in the world, with an average English proficiency score barely surpassing the low proficiency cut-off. That is, the average person in Latin America cannot read a newspaper or understand a TV show in English. A still smaller percentage would be able to understand statistical training about analyzing data with a complex sample and assessment design.

The following are recommendations that we believe could contribute to overcoming the barriers described above:

\section{Develop open-access software to analyze large-scale assessment data}

Similar to the technical documentation and training events, the IEA has been doing a very good job at making tools for analyzing large-scale assessments data freely available. The IEA's IDB (International Database) Analyzer, Data Visualizer, and the NCES (National Center for Education Statistics) Data Explorer are good examples of this. The Data Visualizer, however, can be used to produce only very basic visualizations of descriptive statistics; the NCES Data Explorer can only be used with a limited number of studies (i.e., PISA, TIMSS, PIRLS, PIAAC, and TALIS). The IDB Analyzer offers greater flexibility and the possibility of running slightly more complex analyses (e.g., linear and logistic regressions). The main limitation of the IDB Analyzer is, however, that it uses either SPSS (e.g., IBM 2013) or SAS (e.g., SAS 2012) as its statistical engine. Both software packages fall in the category of commercial software with expensive licenses. As can be expected, many individuals and institutions in the region cannot afford to purchase access to tools like the IDB Analyzer.

\section{Establish partnerships among national governments, international organizations, and academic institutions in Latin America.}

We believe that these kind of partnerships can be the vehicle to develop solutions to several of the issues described above. For example, some of the IEA materials are already being translated into Spanish by organizations in Latin America. This practice could be conducted in a systematic

3 More information about the IEA's training activities can be found here: https://www.iea.nl/research-services/training 
fashion through agreements between the IEA and its partner institutions in Latin American countries (e.g., the Colombian Institute for Educational Evaluation or the Chilean Agency for the Quality of Education), or with other international organizations with a strong presence in Latin America (e.g., OREALC/UNESCO, the Organization of Ibero-American States, or the InterAmerican Development Bank). The translations of these documents could then be disseminated via the IEA's institutional channels or through other institutions dedicated to providing centralized repositories of research data, like the initiative housed at the University of Michigan, Civic Learning, Engagement, and Action Data Sharing (CivicLEADS). ${ }^{4}$

These partnerships could also constitute a platform for the establishment of a capacity-building strategy in the region. IEA has developed a sound structure for the delivery of training on the analysis of secondary data from large-scale assessments. The structure developed by IEA could be combined with the expertise existing in the region (especially the network of researchers working with ICCS data). There are also mechanisms developed by other international organizations like OREALC/UNESCO (i.e., the capacity building strategy developed for the Regional Comparative and Explanatory Study [ERCE]). These or similar partnerships could provide the conditions necessary to offer high-quality training in Spanish and in locations more accessible to those interested in the region.

Another promising partnership could include the agencies in charge of developing teacher training programs. In a recent review of the initial teacher education programs in citizenship in Latin America carried out by UNESCO (2017), it was concluded that one of the greatest challenges in preparing teachers for citizenship education is overcoming the predominantly theoretical approach in order to promote didactic and practical training of future teachers. This is especially true because of differences between countries in whether there are subjects designated for civic education, or whether this is a transversal or cross-curricular topic. ICCS is in a privileged position to provide the empirical evidence needed to address this challenge since it collects extensive information on teaching practices associated with knowledge about, and attitudes toward, civics and citizenship (Schulz et al. 2016). Examples of studies focusing on the identification of successful teaching practices in this area based on analyses of ICCS can be found in, for example, Treviño et al. (2017) and Carrasco and Irribarra (2018).

Finally, these collaborations could also focus on the development of regional research projects to strengthen capacity. The projects could have a component of secondary analysis of ICCS data, but could also include a component of collecting primary data either quantitative or qualitative. This methodological design would expand the range of questions that can be answered only with secondary analysis. For example, an initial secondary analysis of ICCS data could be used to identify interesting patterns (e.g., students who perform better than expected according to their socioeconomic conditions, or a school reporting low-levels of violence despite being in violent social environments). Then, qualitative case studies could be used to identify the causal mechanisms underlying these patterns. Furthermore, these projects could be configured in a way that partner well-established institutions with less experienced ones in order to take advantage of existing critical expertise and, at the same time, to build capacity in other countries/institutions in the region.

4 More information about this project can be found here: https://www.icpsr.umich.edu/icpsrweb/content/civicleads/ index.html

5 During the publication process of this volume, a new piece of software has been released. This software is opensource, has a user-friendly interface, and has been specifically designed to analyze ILSA data. More information can be found here: http://ralsa.ineri.org/ 


\section{Develop user-friendly, open-source software to analyze large-scale assessment data ${ }^{5}$}

The development of a training strategy for the Latin American region could be coupled with the development of open-source, user-friendly software alternatives for the analysis of data. It is important that open-source software be free. The adoption of open-source software would contribute to eliminating the economic and technical barriers that currently affect an important proportion of researchers in the region; the software alternatives currently available for analyzing international large-scale assessment data require the user to buy expensive licenses of proprietary software. Open-source software is not only free to use, but also free to distribute and modify. The fact that this source code is accessible and is continuously being employed by a large community of users results in the code being secure and stable. Furthermore, because it uses open standards accessible to everyone, it does not have the problem of incompatible formats, or platforms that exist in proprietary software. That means that it can be used in Windows, Mac, or Linux computers. The main disadvantage of open-source software, however, is that it is not straightforward to use. Open-source operating systems like Linux and software packages like $\mathrm{R}$ require considerable effort to master them. So, for this recommendation to work in an efficient manner, it would be advisable to develop a user-friendly interface to facilitate the use of open-source software. Specifically, R could be used for the analysis; a user-friendly interface, similar to the IDB Analyzer, should be developed to make it possible to use it without having programming knowledge.

\section{Include concepts that have proved to be relevant for Latin America in subsequent international instruments of ICCS}

Examples of this are the items and scales about authoritarianism and tolerance toward ethnic minorities. As Bonikowski (2017) points out, scholarly and journalistic accounts of the recent successes of radical-right politics in Europe and the United States, including the Brexit referendum and the Trump campaign, tend to conflate three phenomena: populism, ethno-nationalism, and authoritarianism. Additionally, changes in political participation disengaging from traditional channels and using alternatives even violent channels in several Latin American countries, and in other regions of the world, bring several questions about the future of democracy. Bringing more tailored attitudinal measures into the studies would provide invaluable information to address issues that are relevant across regions of the world, while taking advantage of the knowledge already developed in these areas by Latin American researchers.

\section{Summary}

In summary, in describing the landscape of the research that has built on the ICCS data collected in Latin America, we have identified a small but thriving community of researchers committed to the improvement of civic and citizenship education in the region. We have identified what we consider to be the main barriers to increasing the impact of ICCS in the policy and practice discussions of the region. These include the limited number of researchers with the expertise to analyze and interpret large-scale assessment data, the disconnection between the teacher training programs and the empirical evidence provided by studies like ICCS, as well as the lack of technical documentation and the limited number of training events available in Spanish. There is also the lack of an open-access, user-friendly software to analyze large-scale assessment data.

While this list of barriers appeared quite daunting, we have also identified some possible strategies to overcome them. These strategies depend heavily on the community of researchers that has been developed as a result of the participation of Latin American countries in CIVED and the two cycles of ICCS. This community includes not only academics from a variety of disciplines, but also policymakers and practitioners. Current and new partnerships between national governments, international organizations, and academic institutions could constitute a platform for the establishment of a capacity-building strategy in the region. This initiative would 
include the development of open-source, user-friendly software to analyze data from large-scale assessments, along with the training of new experts in the field. The new experts in the field would include those who are content experts, but lack the technical expertise to analyze ICCS data; but also those who have the statistical expertise, but lack the knowledge in the field of civic and citizenship education, or they lack the experience in communicating to non-specialist audiences. Finally, long-term partnerships could also allow further collaboration between the agencies in charge of initial teacher education programs, and the researchers working on the identification of successful teaching practices.

\section{References}

Amadeo, J.-A., Torney-Purta, J., Lehmann, R., Husfeldt, V., \& Nikolova, R. (2002). Civic knowledge and engagement: an IEA study of upper secondary students in sixteen countries. Amsterdam, the Netherlands: International Association for the Evaluation of Educational Achievement (IEA).

Bonikowski, B. (2017). Ethno-nationalist populism and the mobilization of collective resentment. The British Journal of Sociology, 68(S1), S181-S213. https://doi.org/10.1111/1468-4446.12325

Caro, D. H., \& Schulz, W. (2012). Ten hypotheses about tolerance toward minorities among Latin American adolescents. Citizenship, Social and Economics Education, 11(3), 213-234. https://doi.org/10.2304/ csee.2012.11.3.213

Carrasco, D., \& Irribarra, D. T. (2018). The role of classroom discussion. In A. Sandoval-Hernández, M. M. Isac, \& D. Miranda (Eds.), Teaching tolerance in a globalized world (pp. 87-101). Cham, Switzerland: Springer.

Castillo, J. C., Miranda, D., Bonhomme, M., Cox, C., \& Bascopé, M. (2014a). Social inequality and changes in students' expected political participation in Chile. Education, Citizenship and Social Justice, 9(2), 140-156. https://doi.org/10.1177/1746197914520650

Castillo, J. C., Miranda, D., Bonhomme, M., Cox, C., \& Bascopé, M. (2014b). Mitigating the political participation gap from the school: the roles of civic knowledge and classroom climate. Journal of Youth Studies, O(0), 1-20. https://doi.org/10.1080/13676261.2014.933199

Castillo, J. C., Miranda, D., Bonhomme, M., Cox, C., \& Bascopé, M. (2015). Mitigating the political participation gap from the school: the roles of civic knowledge and classroom climate. Journal of Youth Studies, 18(1), 16-35. https://doi.org/10.1080/13676261.2014.933199

Collado, D., Lomos, C., \& Nicaise, I. (2015). The effects of classroom socioeconomic composition on student's civic knowledge in Chile. School Effectiveness and School Improvement, 26(3), 415-440. https:// doi.org/10.1080/09243453.2014.966725

Education First. (2018). EF EPI 2018 - EF English Proficiency Index. https://www.ef.co.uk/epi/

García-Cabrero, B., Pérez-Martínez, M. G., Sandoval-Hernández, A., Caso-Niebla, J., \& Díaz, C. (2016). Assessing two theoretical frameworks of civic engagement. JSSE-Journal of Social Science Education, 38-52.

García-Cabrero, B., Sandoval-Hernández, A., Treviño, E., Diazgranados-Ferrans, S., \& Martínez, G. (Eds.). (2017). Civics and Citizenship: Theoretical Models and Experiences in Latin America. Amsterdam, the Netherlands: Sense Publishers.

IBM. (2013). IBM SPSS Statistics (Version 22.0). Somers, NY: IBM Corporation.

Knowles, R. T., Torney-Purta, J., \& Barber, C. (2018). Enhancing citizenship learning with international comparative research: Analyses of IEA civic education datasets. Citizenship Teaching \& Learning, 13(1), 7-30. https://doi.org/info:doi/10.1386/ctl.13.1.7_1

Martínez, M. L., Cumsille, P., Loyola, I., \& Castillo, J. C. (2020). Patterns of civic and political commitment in early adolescence. The Journal of Early Adolescence, 40(1). https://doi.org/10.1177/0272431618824714

Miranda, D. (2018). Desigualdad y ciudadanía: una aproximación intergeneracional. [ Unpublished doctoral tesis], Pontificia Universidad Católica de Chile.

Miranda, D., Castillo, J. C., \& Sandoval-Hernández, A. (2015). Desigualdad y conocimiento cívico: Chile en comparación internacional. In C. Cox, \& J. C. Castillo (Eds.), Aprendizaje de la Ciudadanía. Contextos, Experiencias y Resultados (pp. 487-524). Santiago, Chile: Ediciones UC.

Miranda, D., Castillo, J. C., \& Sandoval-Hernandez, A. (2015). Desigualdad y conocimiento cívico: Chile en comparación internacional. In Aprendizaje de la Ciudadanía. Contextos, Experiencias y Resultados (pp. 487-524). Santiago, Chile: Ediciones Universidad Católica de Chile. 
Miranda, D., Castillo, J. C., \& Sandoval-Hernandez, A. (2017). Young citizens' participation: Empirical testing of a conceptual model. Youth \& Society. https://doi.org/10.1177/0044118X17741024

Reimers, F. (2007). Civic education when democracy is in flux: The impact of empirical research on policy and practice in Latin America. Citizenship and Teacher Education, 3(2), 5-21.

Reimers, F., \& Villegas-Reimers, E. (2011). Sistema Regional de Evaluación y Desarrollo de Competencias Ciudadanas. Evaluación Final. Washington, DC: Banco Interamericano de Desarrollo.

Sandoval-Hernández, A., Isac, M. M., \& Miranda, D. (Eds.). (2018). Teaching tolerance in a globalized world. Cham, Switzerland: Springer.

SAS. (2012). SAS System for Windows (Version 9.4). Cary, NC: SAS Institute.

Schulz, W., Ainley, J., Fraillon, J., Kerr, D., \& Losito, B. (2009). Initial findings from the IEA International Civic and Citizenship Education Study. Amsterdam, the Netherlands: International Association for the Evaluation of Educational Achievement (IEA).

Schulz, W, Ainley, J., Cox, C., \& Friedman, T. (2018). Young people's views of government, peaceful coexistence, and diversity in five Latin American countries: IEA International Civic and Citizenship Education Study 2016 Latin American report. Cham, Switzerland: Springer. https://doi.org/10.1007/978-3-319-95393-9

Schulz, W., Ainley, J., Fraillon, J., Losito, B., \& Agrusti, G. (2016). IEA International Civic and Citizenship Education Study 2016 assessment framework. Cham, Switzerland: Springer. https://doi.org/10.1007/9783-319-39357-5

Schulz, W., Ainley, J., Friedman, T., \& Lietz, P. (2011). ICCS 2009 Latin American report: Civic knowledge and attitudes among lower-secondary students in six Latin American countries. Amsterdam, the Netherlands: International Association for the Evaluation of Educational Achievement (IEA).

Torney-Purta, J., Amadeo, J.-A., \& Andolina, M. W. (2010). A conceptual framework and multimethod approach for research on political socialization and civic engagement. In L. R. Sherrod, J. Torney-Purta, \& C. A. Flanagan (Eds.), Handbook of research on civic engagement in youth (pp. 497-523). Hoboken, NJ: John Wiley \& Sons.

Torney-Purta, J., Amadeo, J.-A., \& Pilotti, F. (2004a). Fortalecimiento de la democracia en las Américas a través de la educación cívica: un análisis empírico que destaca las opiniones de los estudiantes y los maestros. Washington, DC: Organization of American States.

Torney-Purta, J., Amadeo, J.-A., \& Pilotti, F. (2004b). Strengthening Democracy in the Americas through Civic Education: An Empirical Analysis Highlighting the Views of Students and Teachers. Washington, DC: Organization of American States.

Torney-Purta, J., Lehmann, R., Oswald, H., \& Schulz, W. (2001). Citizenship and education in twenty-eight countries: Civic knowledge and engagement at age 14. Amsterdam, the Netherlands: International Association for the Evaluation of Educational Achievement (IEA).

Treviño, E., Béjares, C., Villalobos, C., \& Naranjo, E. (2017). Influence of teachers and schools on students' civic outcomes in Latin America. The Journal of Educational Research, 110(6), 604-618. https://doi.org/1 $0.1080 / 00220671.2016 .1164114$

Treviño, E., Villalobos, C., Béjares, C., \& Naranjo, E. (2018). Forms of youth political participation and educational system: the role of the school for 8th grade students in Chile. Young, 2018(3), 279-303. https://doi.org/10.1177/1103308818787691

UNESCO. (2017). Initial Teacher Education in Citizenship in Latin America. Paris, France: United Nations Educational, Scientific and Cultural Organization.

Valencia Serna, A., \& Vivas Pacheco, H. (2014). La apertura para la discusión en clase y su relación con la educación para la ciudadanía. Revista Colombiana de Educación, (66), 225-244.

Open Access This chapter is licensed under the terms of the Creative Commons Attribution-NonCommercial 4.0 International License (http://creativecommons.org/licenses/by-nc/4.0/), which permits any noncommercial use, sharing, adaptation, distribution and reproduction in any medium or format, as long as you give appropriate credit to the original author(s) and the source, provide a link to the Creative Commons license and indicate if changes were made.

The images or other third party material in this chapter are included in the chapter's Creative Commons license, unless indicated otherwise in a credit line to the material. If material is not included in the chapter's Creative Commons license and your intended use is not permitted by statutory regulation or exceeds the permitted use, you will need to obtain permission directly from the copyright holder. 